\title{
Butyrate and trichostatin A effects on the proliferation/differentiation of human intestinal epithelial cells: induction of cyclin D3 and p21 expression
}

\begin{abstract}
S Siavoshian, J-P Segain, M Kornprobst, C Bonnet, C Cherbut, J-P Galmiche, $\mathrm{H}$ M Blottière
\end{abstract}

\begin{abstract}
Background-Sodium butyrate, a product of colonic bacterial fermentation, is able to inhibit cell proliferation and to stimulate cell differentiation of colonic epithelial cell lines. It has been proposed that these cellular effects could be linked to its ability to cause hyperacetylation of histone through the inhibition of histone deacetylase.

Aim-To analyse the molecular mechanisms of butyrate action on cell proliferation/differentiation and to compare them with those of trichostatin A, a well known inhibitor of histone deacetylase.

Methods-HT-29 cells were grown in the absence or presence of butyrate or trichostatin A. Cell proliferation and cell cycle distribution were studied after DNA staining by crystal violet and propidium iodide respectively. Cell cycle regulatory proteins were studied by western blot and reverse transcription-polymerase chain reaction. Cell differentiation was followed by measuring brush border enzyme activities. Histone acetylation was studied by acid/urea/Triton acrylamide gel electrophoresis.
\end{abstract}

Results-Butyrate blocked cells mainly in the $G_{1}$ phase of the cell cycle, whereas trichostatin $A$ was inhibitory in both $G_{1}$ and $G_{2}$ phases. Butyrate inhibited the mRNA expression of cyclin D1 without affecting its protein expression and stimulated the protein expression of cyclin D3 without affecting its mRNA expression. Trichostatin A showed similar effects on cyclin D1 and D3. Butyrate and trichostatin A stimulated p21 expression both at the mRNA and protein levels, whereas their effects on the expression of cyclin dependent kinases were slightly different. Moreover, butyrate strongly stimulated the activity of alkaline phosphatase and dipeptidyl peptidase IV, whereas trichostatin A had no effect. Finally, a six hour exposure to butyrate or trichostatin A induced histone $\mathrm{H} 4$ hyperacetylation. At 15 and 24 hours, histone $\mathrm{H} 4$ remained hyperacetylated in the presence of butyrate, whereas it returned to control levels in the presence of trichostatin $A$.

Conclusions-The data may explain how butyrate acts on cell proliferation/ differentiation, and they show that trichostatin A does not reproduce every effect of butyrate, mainly because of its shorter half life.

(Gut 2000;46:507-514)

Keywords: butyrate; cyclin D; p21; trichostatin A; colonic epithelial cells; histone acetylation

Butyrate is a short chain fatty acid produced in the human colon by bacterial fermentation of carbohydrates such as dietary fibre. ${ }^{1}$ The large amounts produced are physiologically important for the colonic mucosa. Indeed, butyrate is the major energy substrate for colonic epithelial cells and is also known to exert various biological effects on cultured mammalian cells, including inhibition of cell proliferation and induction of differentiation. ${ }^{23}$ Its therapeutic potential in colon cancer has also been proposed. ${ }^{4}$

The mechanisms by which butyrate regulates cell proliferation/differentiation are still unclear, although it is known to block cell proliferation, mainly in the $G_{1}$ phase of the cell cycle. ${ }^{6}$ Moreover, our previous studies showed that butyrate action is related to $\mathrm{p} 21 / \mathrm{WAF} 1 /$ Cip1 stimulation and cyclin D expression. ${ }^{7}$

The most commonly reported mechanism by which butyrate modulates gene expression involves an alteration of chromatin structure subsequent to increased histone acetylation. Butyrate is a potent inhibitor of histone deacetylase, which leads to histone hyperacetylation. $^{89}$ It is generally assumed that histone hyperacetylation results in relaxation of the chromatin structure, thereby making DNA accessible to a variety of transcription factors. ${ }^{10}{ }^{11} \mathrm{~A}$ cDNA encoding a human histone deacetylase catalytic subunit has been cloned, the predicted protein sequence of which is very similar to a yeast transcriptional regulator. ${ }^{12}$ This finding confirms that histone deacetylase is an important regulator of eukaryotic transcription. A variety of biological phenomena such as cell cycle blockade and/or differentiation induced by butyrate may be ascribed to this histone hyperacetylation process. However, the role of histone acetylation in butyrate related biological effects needs to be clarified.

Abbreviations used in this paper: DMSO, dimethyl sulphoxide; PBS, phosphate buffered saline; RT-PCR, reverse transcription-polymerase chain reaction. 
Trichostatin A is structurally unrelated to butyrate and was originally reported to be a fungistatic antibiotic. It can cause potent reversible inhibition of mammalian histone deacetylase at nanomolar concentrations both in vivo and in vitro, ${ }^{13}$ appreciable induction of Friend leukaemia cell differentiation, ${ }^{14}$ and inhibition of cell cycle progression in rat fibroblasts. ${ }^{15}$ It appears to be a promising tool for analysing the many functions of histone hyperacetylation in cell proliferation and differentiation. For example, it reproduced the amplification of a viral transgene product achieved with butyrate in cells infected with E1 defective adenovirus, and it has been shown that inhibitors of histone deacetylase-for example, butyrate and trichostatin A-can amplify adenoviral transgene expression. ${ }^{16}$ Huang and colleagues ${ }^{17}$ showed that trichostatin A, like butyrate, can inhibit interleukin- 8 mRNA expression in a dose dependent manner in Caco-2 cells.

We have previously shown that butyrate inhibition of cell proliferation is linked to increased expression of cyclin D and p21/ WAF $1 /$ Cip 1 and inhibition of $\operatorname{cdk} 2 .^{7}$ In the present study, we further investigate the mechanisms of butyrate action by analysing cyclin D subtypes at both the protein and mRNA level and by time course analysis of the effects of butyrate on $\mathrm{p} 21 \mathrm{mRNA}$ and protein. Finally, we compare the respective effects of butyrate and trichostatin A on cell proliferation, the expression of cell cycle regulatory proteins ( $\mathrm{p} 21$, cyclin D1, cyclin D3, cdk2, cdk4, cdk6, etc), cell differentiation, and histone hyperacetylation in HT-29 colonic epithelial cells.

\section{Materials and methods}

CELL CULTURE AND REAGENTS

HT-29 cells were maintained in Dulbecco's modified Eagle's medium supplemented with $10 \%$ fetal calf serum, $2 \mathrm{mM}$ L-glutamine, 50 $\mathrm{U} / \mathrm{ml}$ penicillin, and $50 \mathrm{mg} / \mathrm{ml}$ streptomycin at $37^{\circ} \mathrm{C}$ in a $5 \% \mathrm{CO}_{2}$ incubator. HBL-100 human mammary epithelial cells cultured in RPMI supplemented with the same compounds were used as a positive control for $\mathrm{p} 16$ expression. ${ }^{18}$ All tissue culture reagents were from Gibco (Cergy Pontoise, France). Butyrate was from Sigma (L'Isle Dabeau Chesne, France). Trichostatin A, generously provided by $\operatorname{Dr} M$ Yoshida (Department of Biotechnology, University of Tokyo, Japan), was dissolved in dimethyl sulphoxide (DMSO). SW 1116, LS174T, Caco-2, HCT-116, and IEC-6 cell lines were also used.

CELL PROLIFERATION ASSAY

Cells were seeded in 24 -well plates $\left(10^{4}\right.$ cells/well) and allowed to grow for one day before being exposed to trichostatin A (0.05$1 \mu \mathrm{M})$ or butyrate $(1-8 \mathrm{mM})$ for three to eight days (exponential growth phase). Cell proliferation was assessed by a colorimetric assay using crystal violet (Sigma), a cytochemical stain that binds to chromatin, as described elsewhere. ${ }^{19}$ Briefly, viable cells were fixed in methanol for 15 minutes after washes to remove dead cells. Plates were then air dried and stained with $0.1 \%$ crystal violet for five minutes at room temperature before being emptied, washed with distilled water, and air dried. Bound dye was solubilised in $2 \%$ sodium deoxycholate (Sigma) for 30 minutes at $37^{\circ} \mathrm{C}$ and transferred to 96-well microtitre plates. Absorbance in each well was measured at 630 nm using a Dynatech MR 600 ELISA plate reader.

ASSAY OF ENZYME ACTIVITY

One week after confluence, cells were exposed for a week to trichostatin A $(0.05-0.5 \mu \mathrm{M})$ or butyrate $(5 \mathrm{mM})$, and enzyme activities were then determined on cell homogenates. Alkaline phosphatase expression was measured as described elsewhere, ${ }^{20}$ using $p$-nitrophenyl phosphate as substrate. Dipeptidyl aminopeptidase IV activity was measured using $1.5 \mathrm{mM}$ glycylL-proline-4-nitroanilide (Sigma) as substrate in $75 \mathrm{mM}$ glycine/ $\mathrm{NaOH}$ buffer ( $\mathrm{pH}$ 8.7). Results are expressed as milliunits/mg protein, one unit being defined as the activity that hydrolyses $1 \mathrm{mmol} \mathrm{substrate} / \mathrm{min}$ at $37^{\circ} \mathrm{C}$. Proteins were measured spectrophotometrically using the Dc Protein Assay (Bio-Rad, Ivry sur Seine, France).

\section{IMMUNOBLOTTING}

Cells were plated on to $75 \mathrm{~cm}^{2}$ flasks at a density of $2 \times 10^{6}$ cells per flask and then, after 24 hours, exposed to complete medium for one day in the presence or absence of increasing concentrations of trichostatin A, butyrate, or DMSO. After three washes with phosphate buffered saline (PBS), the cells were incubated for one hour at $4^{\circ} \mathrm{C}$ in $500 \mu l$ lysis buffer consisting of $10 \mathrm{mM}$ Tris/ $\mathrm{HCl}(\mathrm{pH} 7.4), 20 \mathrm{mM}$ $\mathrm{NaCl}, 5 \mathrm{mM} \mathrm{MgCl}, 0.5 \%$ Nonidet P40, and $0.1 \mathrm{mM}$ phenylmethanesulphonyl fluoride. After centrifugation at $10000 \mathrm{~g}$ for 10 minutes at $20^{\circ} \mathrm{C}$, the protein content of the supernatant was determined. Total proteins $(15 \mu \mathrm{g})$ from controls or extracts treated with trichostatin A or butyrate were resolved by sodium dodecyl sulphate/polyacrylamide gel electrophoresis $(12 \%$ gel) together with prestained protein molecular mass standards (Bio-Rad). Gels were then blotted on to poly(vinylidene difluoride) membranes (Sigma). On completion of the transfer, the blots were blocked overnight at $4^{\circ} \mathrm{C}$ with PBS containing $6 \%$ non-fat milk. Membranes were incubated with primary antibodies at a 1:200 dilution in 3\% milk/PBS for one hour at room temperature. Rabbit polyclonal antibodies directed against cyclin D3, cdk2, cdk4, cdk6, p16, and p21, as well as mouse monoclonal antibody against cyclin $\mathrm{D} 1$, were obtained from Santa Cruz Biotechnology (Santa Cruz, California, USA). The blots were washed three times and then incubated with biotin conjugated anti-rabbit IgG (Sigma) diluted $1: 500$ in $3 \%$ milk/PBS or with antimouse IgG (diluted 1:200; Caltag, Burlingame, California, USA) for one hour at room temperature. After additional washes, the blots were incubated for one hour with streptavidinperoxidase complex (Sigma) diluted 1:500 in $3 \%$ milk/PBS. After additional washes, the 
specific bands were detected using the ECL detection system according to the manufacturer's instructions (Amersham, Les Ulis, France). Bands were visualised as negative or positive staining depending on the use of polaroid or radiographic films.

\section{CELL CYCLE ANALYSIS}

HT-29 cells in exponential growth phase were synchronised by exposing the culture to fetal calf serum-deprived Dulbecco's modified Eagle's medium for 24 hours. Cells were then exposed to complete medium in the presence or absence of trichostatin A $(0.5 \mu \mathrm{M})$, butyrate ( $5 \mathrm{mM}$ ), or DMSO for 24 hours before being harvested and stained with propidium iodide using the DNA-Prep Coulter kit (Coulter, Margency, France) according to the manufacturer's instruction. Cell DNA content was then analysed by flow cytometry using an EPICS XL (Coulter). Raw data for the distribution of DNA content retrieved from the EPICS XL were expressed as the percentage of $G_{0} / G_{1}$ through $\mathrm{G}_{2} / \mathrm{M}$ populations. Multicycle $\mathrm{AV}$ software (Phoenix Flow Systems, San Diego, California, USA) was used to generate DNA content histograms and facilitate data analysis.

REVERSE TRANSCRIPTION-POLYMERASE CHAIN REACTION (RT-PCR) ANALYSIS

Cells were plated on to $25 \mathrm{~cm}^{2}$ flasks at a density of $2 \times 10^{6}$ cells per flask. After 24 hours, cells were exposed to complete medium in the presence or absence of trichostatin A $(0.1,1$ $\mu \mathrm{M})$ and butyrate $(5 \mathrm{mM})$ for one day. Total RNA was extracted by the guanidinium/ phenol/chloroform procedure, as described by Chomczynski and Sacchi. ${ }^{21}$ Reverse transcription was performed on $2 \mu \mathrm{g}$ total RNA in a reaction volume of $20 \mu \mathrm{l}$ with $4 \mu \mathrm{l}$ of $5 \times \mathrm{RT}$ buffer (Life Technologies, Cergy Pontoise, France), $2 \mu \mathrm{l} 50 \mu \mathrm{M}$ random primers (pdN6; Pharmacia, Orsay, France), $1.5 \mu \mathrm{l} 10 \mathrm{mM}$ dNTP mix (Pharmacia), 8 U RNAse inhibitor (Pharmacia), $2 \mu 10.1 \mathrm{M}$ dithiothreitol, and 200 U Superscript II Moloney murine leukaemia virus reverse transcriptase (Life Technologies). The reaction mixture was incubated for 45 minutes at $40^{\circ} \mathrm{C}$, and the volume was then adjusted to $100 \mu \mathrm{l}$ with distilled water.

PCR amplification was then performed with $1.25,2.5$, and $5 \mu \mathrm{l}$ (1:2 dilutions) of the cDNA solution supplemented with $5 \mu \mathrm{l}$ of $10 \times$ Goldstar buffer, $3 \mu \mathrm{l} \mathrm{MgCl}_{2}(25 \mathrm{mM}), 1 \mu \mathrm{dNTP}$ mix $(10 \mathrm{mM}), 1 \mu \mathrm{l}$ of each solution of primers $(50 \mu \mathrm{M}), 0.5 \mathrm{U}$ Goldstar DNA polymerase (Eurogentec, Seraing, Belgium), and water to a final volume of $50 \mu \mathrm{l}$. PCR conditions were: 28 cycles for $\beta$-actin (primers 5'-GGCATCG TGATGGACTCCG-3' and 5'-GCTGGAA GGTGGACAGCGA-3'); 28 cycles for cyclin D3 (primers 5'-CTGGCCATGAACTACCT GGA-3' and 5'-CCAGGAAATCATGTGCA ATC-3'); 35 cycles for cyclin D1 (primers 5'-GAAAGTAGGGACCTCAGAGG-3' and 5'-CTGTCCTCCCTCACACGTCA-3'); 35 cycles for p21 (primers 5'-CCCAGTGGA CAGCGAGCAGC-3' and 5'-ACTGCAGGC TTCCTGTGGGC-3'). Each PCR cycle con- sisted of 40 seconds at $92^{\circ} \mathrm{C}, 40$ seconds at $58^{\circ} \mathrm{C}$, and 50 seconds at $72^{\circ} \mathrm{C}$.

HISTONE ANALYSIS BY ACID/UREA/TRITON ELECTROPHORESIS

Histones were extracted as described previously. ${ }^{13}$ Briefly, $2 \times 10^{6}$ HT-29 cells were cultured for six, 15, and 24 hours without or with trichostatin $\mathrm{A}(1 \mu \mathrm{M})$ or butyrate $(5 \mathrm{mM})$, harvested using a rubber policeman, and washed with PBS. Cells were resuspended in ice cold lysis buffer $(10 \mathrm{mM}$ Tris/ $\mathrm{HCl}, 50 \mathrm{mM}$ $\mathrm{Na}_{2} \mathrm{SO}_{3}, 10 \mathrm{mM} \mathrm{MgCl}, 4 \mathrm{M}$ sucrose, $1 \%$ Triton $\mathrm{X}-100, \mathrm{pH}$ 6.5). After homogenisation, two washes with lysis buffer followed by centrifugation $(1000 \mathrm{~g}, 10 \mathrm{~min})$ and one with $10 \mathrm{mM}$ Tris/ $\mathrm{HCl}, 13 \mathrm{mM}$ EDTA, $\mathrm{pH} 7.4$, the pellet was suspended in $0.2 \mathrm{M} \mathrm{H}_{2} \mathrm{SO} 4$. After one hour at $4^{\circ} \mathrm{C}$ followed by centrifugation at $20000 \mathrm{~g}$, the supernatant was recovered, mixed with $1 \mathrm{ml}$ acetone, and proteins were allowed to precipitate at $-20^{\circ} \mathrm{C}$ overnight. The acid soluble histone fraction was air dried and dissolved in loading buffer $(7.4 \mathrm{M}$ urea, $1.3 \mathrm{M}$ $\mathrm{NH}_{3}, 10 \mathrm{mM}$ dithiothreitol, $0.1 \%$ pyronine $\mathrm{Y}$ ). Histone acetylation was evaluated by fractionation on acid/urea/Triton acrylamide gel as described. ${ }^{13}$

\section{Results}

TRICHOSTATIN A AND BUTYRATE INHIBITION OF HT-29 CELL PROLIFERATION

The effect of trichostatin A and butyrate on cell proliferation was compared in the HT-29 cell line using crystal violet staining. Cells were cultured alone or with different concentrations of trichostatin A or butyrate for three, six, and eight days. Trichostatin A and butyrate inhibited cell proliferation dose dependently (fig 1). Trichostatin A was able to inhibit cell growth at concentrations of $0.05 \mu \mathrm{M} \quad(\mathrm{p}<0.05)$ and above, optimal inhibition being obtained at $0.25 \mu \mathrm{M}$. It is noteworthy that the DMSO used for trichostatin A solubilisation had no effect on HT-29 cell proliferation (data not shown). Butyrate inhibited cell growth at concentrations starting from $1 \mathrm{mM}$, with complete inhibition occurring at $8 \mathrm{mM}$. Cell viability assessed by trypan blue exclusion, floating cell counting, and cell morphology showed that the effect of butyrate and trichostatin $\mathrm{A}$ at the optimal concentrations was not due to a cytotoxicity of the compounds (data not shown).

DIFFERENT EFFECTS OF BUTYRATE AND TRICHOSTATIN A ON CELL CYCLE PROGRESSION After 24 hours of exposure to complete culture medium, $46 \%$ of the cells were in $\mathrm{G}_{1}$ phase and $43 \%$ in $S$ phase (fig 2). In the presence of sodium butyrate $(5 \mathrm{mM})$, the percentage of cells in $G_{1}$ phase was sharply increased, whereas a dramatic decrease of cells in $S$ phase occurred and no consistent effect was noted in $\mathrm{G}_{2}$ phase. In the presence of trichostatin A $(0.5$ $\mu \mathrm{M}), 58 \%$ of cells were found in $\mathrm{G}_{1}$ phase and $34 \%$ in $G_{2}$. Again, DMSO had no effect on cell cycle parameters (data not shown). 

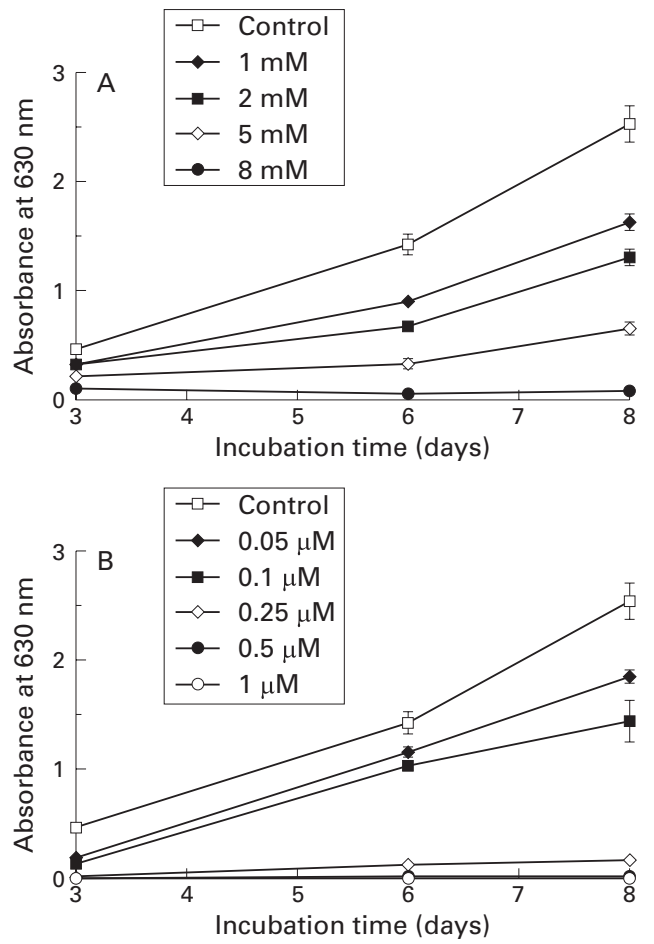

Figure 1 Growth curve of HT-29 cells estimated by the crystal violet staining method. Each point corresponds to the mean and SEM of experiments carried out in quadruplicate. The results presented are from one experiment representative of the four performed. Cells were cultured without or with increasing concentrations of butyrate $(A)$ and trichostatin $A(B)$, as indicated.

SIMILAR EFFECTS OF BUTYRATE AND

TRICHOSTATIN A ON CYCLIN D PROTEIN AND mRNA EXPRESSION

A comparison of the effect of butyrate and trichostatin A on cyclin D subtypes showed that cyclin D1 was constitutively expressed by HT-29 cells but that cyclin D3 was not detected. After one day of incubation with increasing concentrations of butyrate, the protein level of cyclin D1 remained unchanged, while cyclin D3 expression was strongly stimulated (fig 3). A 30-fold increase was obtained for a $5 \mathrm{mM}$ butyrate concentration, as measured by densitometric analysis of the bands. Similar results were observed in the presence of trichostatin A. mRNA expression of cyclin D1 and D3 were then studied by RT-PCR (fig 4). A decrease in cyclin D1 mRNA was noted after 24 hours of culture in the presence of $5 \mathrm{mM}$ butyrate. A similar decrease was observed in the presence of 0.5 $\mu \mathrm{M}$ (not shown) and $1 \mu \mathrm{M}$ trichostatin A (fig 4). For cyclin D3, the mRNA level remained unchanged after 24 hours of incubation with butyrate and trichostatin A (fig 4).

SIMILAR EFFECTS OF BUTYRATE AND TRICHOSTATIN A ON p21 PROTEIN AND mRNA EXPRESSION

In preliminary experiments, a kinetic study of p21 mRNA and protein expression was performed on HT-29 cells after treatment with $5 \mathrm{mM}$ butyrate (fig 5). p21 mRNA and protein were not detected in control cells. After six hours of incubation with butyrate $(5 \mathrm{mM}), \mathrm{p} 21$ mRNA was detected but not the protein. p21
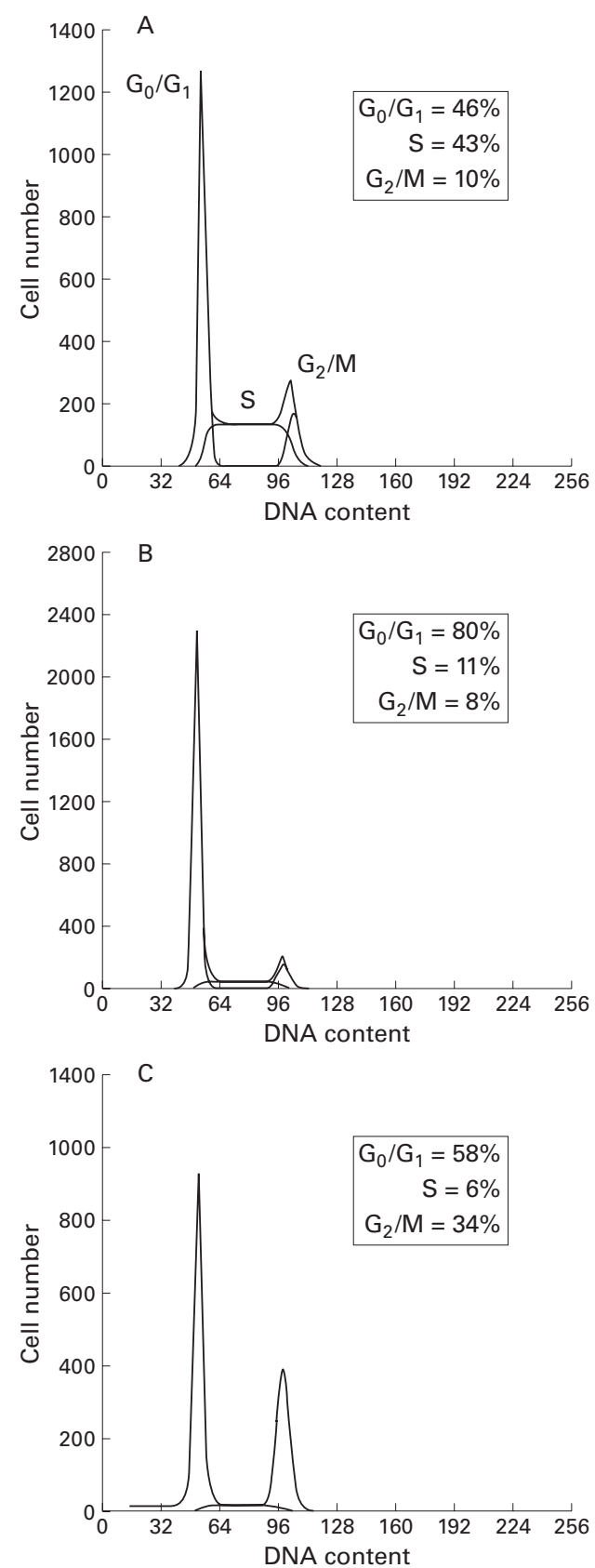

Figure 2 Histograms of DNA content of untreated HT-29 cells $(A)$ and cells treated with $5 \mathrm{mM}$ butyrate $(B)$ or 0.5 $\mu M$ trichostatin $A(C)$. Cells were treated with each substance for 24 hours, and their DNA content was determined as described in Materials and methods. The cell cycle phase distributions (\%) for each treatment are indicated within each panel.

mRNA expression had increased after 12 hours and was stable at 24 hours. At the protein level, p21 was detected at 12 hours, and expression increased up to 24 hours. The effects of butyrate and trichostatin A were then compared at the mRNA and protein level after 24 hours of incubation (fig 6). p21 protein was detected at concentrations above $0.5 \mu \mathrm{M}$ trichostatin A but not at $0.25 \mu \mathrm{M}$. At the mRNA level, $0.5 \mu \mathrm{M}$ (not shown) and $1 \mu \mathrm{M}$ trichostatin A (fig 6A) induced p21 similarly to butyrate. At $0.1 \mathrm{mM}$ trichostatin $\mathrm{A}$, no mRNA was amplified for $\mathrm{p} 21$. 
Cyclin D1

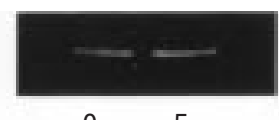

5

Butyrate (mM)

Cyclin D1

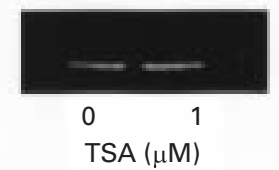

Cyclin D3

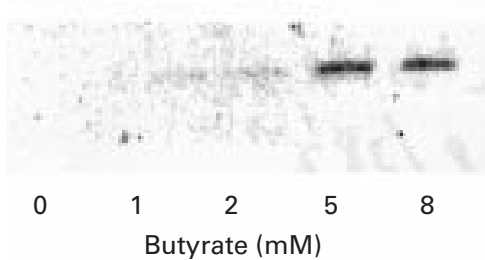

Cyclin D3

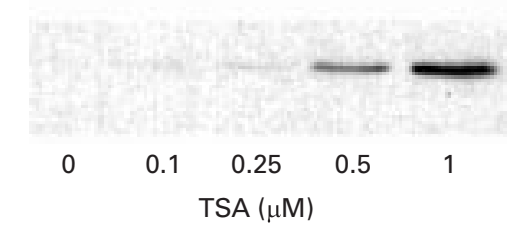

Figure 3 Western blot analysis of cell cycle regulatory protein expression in HT-29 cells treated for 24 hours in the presence of the indicated substances. Equal volumes of whole cell extracts containing $15 \mu \mathrm{g}$ proteins were separated and electrophoretically blotted. Proteins were probed with antibodies to cyclin D1 and D3, as indicated. TSA, trichostatin A.

Cyclin D1

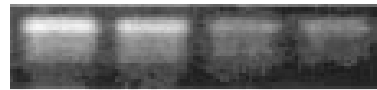

Cyclin D3

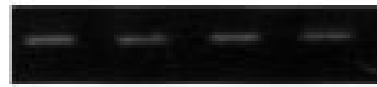

$\beta$-actin

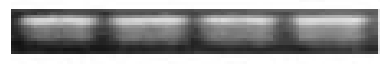

0.1

Butyrate (5 mM)

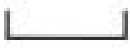

TSA $(\mu \mathrm{M})$

Figure 4 Comparison of the effect of trichostatin $A$ (TSA) and butyrate on cyclin D1 and D3 $m R N A$ as studied by reverse transcription-polymerase chain reaction (RT-PCR). PCR products were analysed on a $1.5 \%$

agarose gel stained with ethidium bromide. Primers and conditions are specified in Materials and methods. $\beta$-Actin is shown as a control. The sizes of the PCR products were $620 \mathrm{bp}$ for $\beta$-actin, $577 \mathrm{bp}$ for cyclin D1, and $264 \mathrm{bp}$ for cyclin D3.

DIFFERENT EFFECTS OF BUTYRATE AND

TRICHOSTATIN A ON CYCLIN DEPENDENT KINASES The expression of $\operatorname{cdk} 2, \operatorname{cdk} 4$, and $\operatorname{cdk} 6$ were studied one day after treatment with increasing concentrations of trichostatin A or with $5 \mathrm{mM}$ butyrate. HT-29 control cells expressed cdk2, cdk4, and cdk6 proteins. After incubation with trichostatin $\mathrm{A}$, the protein level of cdk2 and cdk4 remained unchanged (fig 7), whereas cdk6 decreased. This decrease was first observed at $0.5 \mu \mathrm{M}$ trichostatin $\mathrm{A}$ and became
A

p21

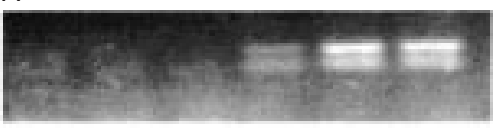

$\beta$-actin
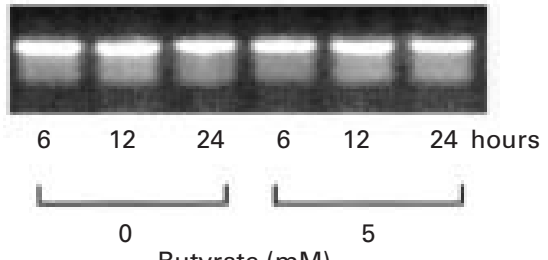

Butyrate (mM)

B

p21

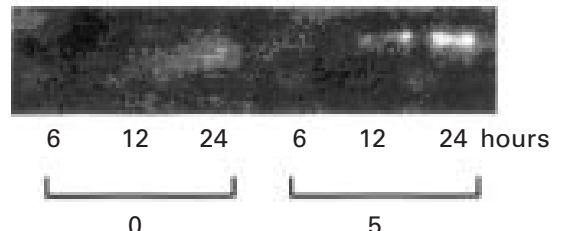

Butyrate (mM)

Figure 5 Kinetic analysis of the effect of butyrate on p21 $m R N A(A)$ and protein $(B)$ expression. HT-29 cells were either exposed to medium alone or to $5 \mathrm{mM}$ butyrate, and total $m R N A$ and proteins were extracted at the indicated time after stimulation. In $(A)$, polymerase chain reaction (PCR) products were analysed on a $1.5 \%$ agarose gel stained with ethidium bromide. Primers and conditions are specified in Materials and methods. In (B), equal volumes of whole cell extracts containing $15 \mu \mathrm{g}$ proteins were separated and electrophoretically blotted. Proteins was probed with antibody to $p 21$.
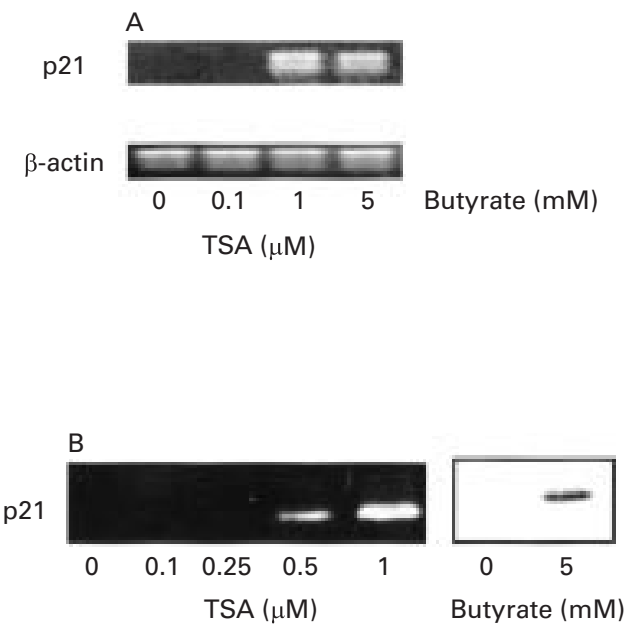

Figure 6 Comparison of the effect of trichostatin A (TSA) at increasing concentrations and butyrate (at 5 $m M)$ on the expression of $21 \mathrm{mRNA}(A)$ and protein $(B)$ in HT-29 cells. In (A), polymerase chain reaction (PCR) products were analysed on a $1.5 \%$ agarose gel stained with ethidium bromide. Primers and conditions are specified in Materials and methods. The sizes of the PCR products were $620 \mathrm{bp}$ for $\beta$-actin and $449 \mathrm{bp}$ for $p 21$. In (B), equal volumes of whole cell extracts containing $15 \mu \mathrm{g}$ proteins were separated and electrophoretically blotted. Proteins were probed with antibody to $p 21$.

maximal at $1 \mu \mathrm{M}$. In contrast, butyrate did not modulate cdk4 and cdk6, and a decrease in cdk2 was obtained.

STIMULATION OF BRUSH BORDER ENZYME ACTIVITY BY BUTYRATE BUT NOT TRICHOSTATIN A The effect of various concentrations of trichostatin A (0.05, 0.1, and $0.5 \mathrm{mM})$ were compared with that of butyrate $5 \mathrm{mM}$ on the 
$\operatorname{cdk} 2$
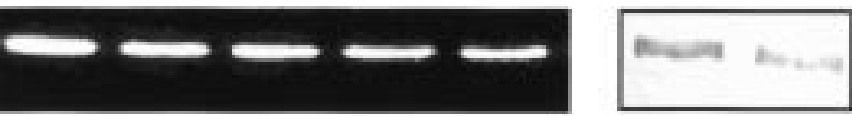

cdk4
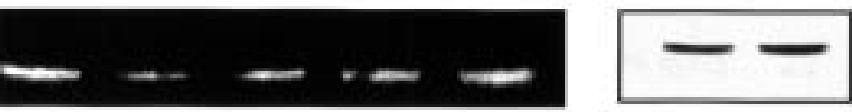

cdk6

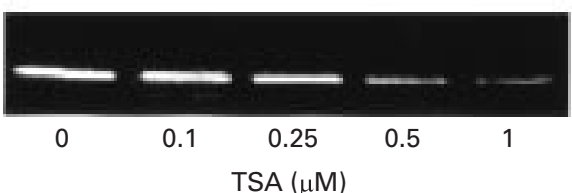

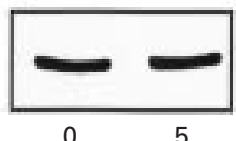

Butyrate (mM)

Figure 7 Effect of trichostatin A (TSA) and butyrate on the expression of cdk2, cdk4, and cdk6 proteins in HT-29 cells. Equal volumes of whole cell extracts containing $15 \mu \mathrm{g}$ proteins were separated and electrophoretically blotted. Proteins were probed with antibodies to the indicated proteins.

Table 1 Effect of seven day exposure to butyrate and trichostatin $A$ on alkaline phosphatase and dipeptidyl aminopeptidase IV activities of HT-29 cells

\begin{tabular}{lcl}
\hline & $\begin{array}{c}\text { Alkaline } \\
\text { phosphatase }\end{array}$ & $\begin{array}{l}\text { Dipeptidyl } \\
\text { aminopeptidase IV }\end{array}$ \\
\hline $\begin{array}{l}\text { Control } \\
\text { Trichostatin A }\end{array}$ & $2.36(0.46)$ & $30.90(0.47)$ \\
$\quad(\mu \mathrm{M})$ & & \\
0.05 & $3.42(0.69)$ & $33.28(0.42)$ \\
0.1 & $3.97(0.12)$ & $32.02(0.18)$ \\
$\quad 0.5$ & $4.72(0.13)$ & $33.78(0.11)$ \\
Butyrate $(5 \mathrm{mM})$ & $71.90(0.69)$ & $55.68(0.32)$ \\
\hline
\end{tabular}

Results are expressed in $\mathrm{mU} / \mathrm{mg}$ as mean $(\mathrm{SEM})(\mathrm{n}=3)$.

activities of alkaline phosphatase and dipeptidyl aminopeptidase IV. HT-29 cells were cultured with trichostatin A or butyrate for seven days before measurement of enzyme activities (table 1). A 35-fold increase in alkaline phosphatase activity was detected with butyrate, but only a very slight increase with trichostatin A. Moreover, butyrate enhanced dipeptidyl aminopeptidase IV, whereas trichostatin A had no effect.

BUTYRATE AND TRICHOSTATIN A INDUCED HISTONE HYPERACETYLATION

The effect of trichostatin A and butyrate on histone acetylation was assessed by HT-29 cells by acid/urea/Triton acrylamide gel electrophoresis (fig 8). Accumulation of triacetylated and tetra-acetylated histone $\mathrm{H} 4$ was observed after six hours of exposure to both drugs. After 15 hours (not shown) and 24 hours in the presence of butyrate, histone $\mathrm{H} 4$ remained hyperacetylated. In contrast, after 15 hours (not shown) and 24 hours, the level of histone $\mathrm{H} 4$ acetylation of cells exposed to trichostatin A was not different from that of cells cultured without trichostatin A.

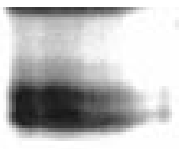

TSA

$24 \mathrm{~h}$

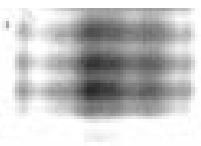

Butyrate $24 \mathrm{~h}$

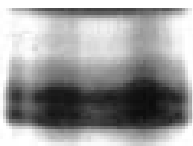

Control

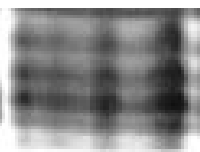

TSA

$6 \mathrm{~h}$

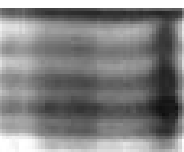

Butyrate

$6 \mathrm{~h}$

Figure 8 Effect of butyrate and trichostatin A (TSA) on histone H4 acetylation. Cells were cultured for six hours and 24 hours in the absence (control) or presence of $5 \mathrm{mM}$ butyrate or $1 \mu \mathrm{M}$ trichostatin A. Histones were then separated by acid/urea/Triton acrylamide gel electrophoresis, and stained with Coomassie blue.

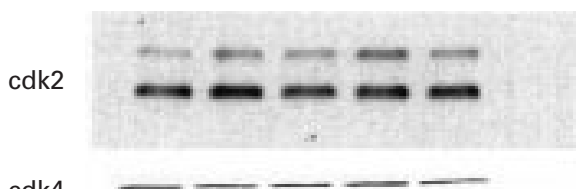

cdk4
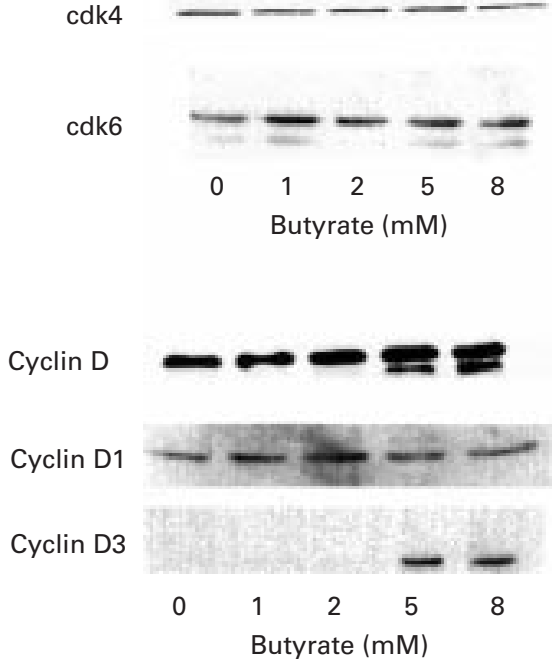

Figure 9 Western blot analysis of cell cycle regulatory protein expression in IEC-6 cells treated for 24 hours in the presence of increasing concentrations of butyrate. Equal volumes of whole cell extracts containing $15 \mu \mathrm{g}$ proteins were separated and electrophoretically blotted. Proteins were probed with antibodies to cdk2, cdk4, cdk6, cyclins D, D1 and D3, as indicated.

EFFECT OF BUTYRATE ON OTHER CELL LINES

Several other intestinal epithelial cell lines were also examined, namely Caco-2, LS174T, SW1116, HCT-116 and the non-tumoral rat cell line IEC-6. As illustrated in fig 9 for IEC-6 cells, the same pattern of modification of cell cycle regulatory proteins as for HT-29 cells was observed for all the cell lines tested. Cyclin D3 was overexpressed with no modulation of cyclin D1; however, the cdk2 level was not regulated by butyrate in IEC-6 cells. Finally, p21 was induced in all cell lines, and p16 remained undetected (not shown).

\section{Discussion}

This study shows that the effect of butyrate on cell proliferation/differentiation was associated with p21 induction at the protein and mRNA level and overexpression of cyclin D3. Moreover, trichostatin A only partly mimics the effects of butyrate. Both compounds induced histone hyperacetylation, but with different kinetics of action.

It is well documented that butyrate inhibits the proliferation of several colorectal cancer cell lines and stimulates their differentiation. ${ }^{22-24}$ Our results show that trichostatin A, like butyrate, can inhibit growth of the HT-29 cell line. Similar results have been reported by McBain and colleagues ${ }^{25}$ who observed that trichostatin A, as well as butyrate, can inhibit the growth of HCT 116 human colon carcinoma cells. As for HCT 116 cells, ${ }^{25}$ our observations show that this effect is not due to cytotoxicity for either compound. Moreover, our study shows that, after 24 hours, butyrate blocked HT-29 cells mainly in the $G_{1}$ phase. This accumulation in the $G_{1}$ phase has been observed in $\mathrm{WiDr}^{26}$ and SW $620^{27}$ human 
colorectal cell lines at 48 hours. It has been reported that, after 12 hours of exposure to butyrate, the percentage of SW 620 cells in the $S$ phase was reduced because of their accumulation in the $G_{1}$ and $G_{2}$ phases. ${ }^{27}$ The accumulation in the $G_{2}$ phase was transient, having decreased by 24 hours, and, after 48 hours, the cells remained in the $G_{1}$ phase. After 24 hours of exposure to trichostatin A, a large percentage (about $35 \%$ ) of the cells was accumulated in $G_{2}$. Yoshida and Beppu ${ }^{15}$ described a similar effect of trichostatin A on 3Y1 rat fibroblast cells. The proliferation of $3 \mathrm{Y} 1$ cells was specifically blocked by trichostatin A at two distinct stages in the cell cycle, first in early- $G_{1}$ phase and then during $\mathrm{G}_{2}$ phase. Thus it appears that butyrate and trichostatin A acted differently on cell cycle progression.

We then studied the effect of butyrate and trichostatin A on cell cycle regulatory proteins involved mainly in the $G_{1}$ phase. In a previous study, ${ }^{7}$ we showed that butyrate strongly stimulates cyclin D expression; however, we did not analyse the subtypes of cyclin D involved. In the present study, we observed that cyclin D1 protein expression was not modulated by butyrate, whereas a decrease was noted at the mRNA level. Our results are at variance with another study which reported that butyrate downregulated cyclin D1 mRNA and protein expression in a mouse fibroblast cell line and a human epidermoid carcinoma cell line. ${ }^{28}$ However, these authors observed no modulation of cyclin D1 in a mammary carcinoma cell line. We also tested several other intestinal cell lines, and observed the same lack of effect of butyrate on cyclin D1. No mRNA for cyclin D2 was detected in HT-29 cells, although normal and other cancerous human intestinal epithelial cells did express it (data not shown). In contrast with cyclin D1, we showed that butyrate stimulated cyclin D3 protein expression in all epithelial cell lines tested, without affecting cyclin D3 mRNA. Cyclins were investigated because their levels vary dramatically in conjunction with cell cycle progression. The periodic accumulation of different cyclins determines the temporal order of cell cycle events, so that cyclin proteolysis is essential for cell cycle progression. Our observations suggest that butyrate may increase the stability of cyclin D3 protein. Further work is needed to clarify how butyrate promotes cyclin D3 stabilisation and whether it decreases cyclin D3 proteolysis. Moreover, this potential stabilisation may also have occurred for cyclin D1 in our model. This increased expression of cyclin D3 may be linked to the differentiation process. Indeed, it has been shown that cyclin D3 was increased in a rat myoblast cell line during terminal differentiation into myotubes, whereas cyclin D1 remained unchanged. ${ }^{29}$ In addition, butyrate is a well known differentiating agent, ${ }^{3}$ and thus may involve cyclin D3. For trichostatin A, we observed the same effect as butyrate on cyclin D1 and D3 mRNA and protein.

We then studied the effect of butyrate and trichostatin A on $\mathrm{p} 21 / \mathrm{WAF} 1 / \mathrm{Cip} 1$ expression. It has been shown that $\mathrm{p} 21$ levels can increase in response to several physiological and chemical inducers of differentiation, including sodium butyrate. ${ }^{70-33}$ The increased expression of this inhibitory protein observed after treatment with trichostatin A and butyrate in HT-29 cells may be responsible for growth inhibition in the $G_{1}$ phase. In fact, p21 inhibits cyclin D-cdk4 kinase, cyclin D-cdk6 kinase, cyclin E-cdk2 kinase, and cyclin A-cdk2 kinase activities to varying degrees. ${ }^{34}$ However, some differences in p21 expression were observed in our study with butyrate and trichostatin A. p21 mRNA and protein were induced at all butyrate concentrations displaying cell growth inhibition - that is, at $1 \mathrm{mM}$ and above ${ }^{7}$ - whereas growth inhibition was noted with trichostatin $\mathrm{A}$ at $0.1 \mu \mathrm{M}$ and $0.25 \mu \mathrm{M}$, but p21 mRNA and protein were not detected. As appreciable inhibition of histone deacetylase has been reported at these trichostatin A concentrations, ${ }^{13}$ histone acetylation may not be sufficient to induce p21. It is noteworthy that, when incubated for 24 hours with cells transiently transfected with a p21 promoterluciferase fusion plasmid, butyrate activated the transgene $^{26}$ and trichostatin A displayed the same activation. ${ }^{35}$

Cyclin-cdk complexes are also regulated by another group of inhibitors, the p16/INK4 family. However, our previous results indicate that p16 is not involved in butyrate induced growth arrest. ${ }^{7}$ Similar results were found with trichostatin A (data not shown).

Butyrate is able to decrease cdk 2 expression without modulating cdk4 and cdk6 expression. ${ }^{7}$ The present report shows that trichostatin A downregulated cdk6 expression, whereas expression of cdk 2 and cdk 4 remained unmodified. This may be related to the difference in cell cycle progression noted in the presence of the two compounds. It is noteworthy that cdk 2 was not modulated by butyrate in IEC- 6 cells. This suggests that cdk 2 regulation is not a key factor in the effect of butyrate on cell proliferation.

We then compared the effects of butyrate and trichostatin A on brush border enzyme activities used as markers of cell differentiation. $^{36}$ Butyrate greatly increased alkaline phosphatase and dipeptidyl aminopeptidase IV activities in many colon carcinoma cell lines, ${ }^{22} 24$ whereas trichostatin A modulated alkaline phosphatase and dipeptidyl aminopeptidase IV enzyme activities only slightly. This suggests that the regulation of differentiation by butyrate may be independent of histone acetylation or at least involve different pathways. Moreover, the presence of a butyrate responsive element on the promoter region of alkaline phosphatase and dipeptidyl aminopeptidase IV genes may also explain these observations. ${ }^{3738}$

Overall, our observations indicate that butyrate was active at millimolar concentrations, whereas trichostatin A displayed its effects at nanomolar concentrations. The difference in the efficiency of the two compounds may relate to nucleus accessibility. Butyrate may be partly $\beta$-oxidised in cells before reaching the histone deacetylase. Moreover, the two compounds show different histone $\mathrm{H} 4$ hyperacetylation 
kinetics. The effect of butyrate on histone $\mathrm{H} 4$ hyperacetylation was maintained after 24 hours, whereas the trichostatin A effect on histone $\mathrm{H} 4$ was no longer detectable after 15 hours. This is in agreement with other studies. ${ }^{39}$ Indeed, after 16 hours of exposure to butyrate, most $\mathrm{H} 4$ histones are acetylated, whereas around $60 \%$ of $\mathrm{H} 4$ is acetylated in the presence of trichostatin A after two hours and the amount of non-acetylated $\mathrm{H} 4$ returns to control levels by 16 hours. This difference in kinetics may explain our observations. Moreover, butyrate induces phosphorylation of histone $\mathrm{H} 3,{ }^{40}$ hypermethylation of $\mathrm{DNA},{ }^{41}$ and activation of a protein phosphatase. ${ }^{42}$ It is still not apparent whether trichostatin A displays similar effects.

It may be concluded that the butyrate effect on cell proliferation/differentiation may be linked to its ability to induce expression of cyclin D3 and p21 protein. Our observations support the claim for the therapeutic potential of butyrate and trichostatin $\mathrm{A}$ in the treatment of colorectal carcinoma. Indeed, it has been shown that p21 expression is reduced in adenomas and colorectal carcinoma. ${ }^{43} 44$ The ability of butyrate to induce p21 may define a new strategy for inhibiting cancer cell proliferation, because there is probably no mutation of the p21 gene in colorectal cancer. ${ }^{45}{ }^{46}$ Finally, the relation between cyclin D3 expression and colon cancer remains to be established.

1 Cummings JH, Pomare EW, Branch WJ, et al. Short chain fatty acids in human large intestine, portal, hepatic and venous blood. Gut 1987;28:1221-7.

2 Chung YS, Song IS, Erickson RH, et al. Effect of growth and sodium butyrate on brush border membraneassociated hydrolases in human colorectal cancer cell lines. Cancer Res 1985;45:2976-82

3 Kruh J, Tichonicky L, Defer N. Effect of butyrate on gene expression. In: Binder HJ, Cummings J, Soergel KH, eds.

4 Perrin P, Cassagnau E, Burg C, et al. An interleukin 2 sodium butyrate combination as immunotherapy of rat colon cancer peritoneal carcinomatosis. Gastroenterology colon cancer perito

5 Hague A, Elder DJE, Hicks DJ, et al. Apoptosis in colorectal tumour cells: induction by the short chain fatty acids butyrate, propionate and acetate and by the bile salt deoxybutyrate, propionate and acetate and

6 Darzynkiewicz Z, Traganos F, Xue SB, et al. Effect of n-butyrate on cell cycle progression and in situ chromatin structure of L1210 cells. Exp Cell Res 1981;136:279-93.

7 Siavoshian S, Blottière HM, Cherbut C, et al. Butyrate stimulates cyclin D and p 21 and inhibits cyclin-dependen kinase expression in HT-29 colonic epithelial cells. Biochem Biophys Res Commun 1997;232:169-72.

8 Riggs MG, Whittaker RG, Neumann J, et al. n-Butyrate causes histone modification in HeLa and Friend erythroleukaemia cells. Nature 1977;268:462-4.

9 Cousens LS, Gallwitz D, Alberts BM. Different accessibilities in chromatin to histone acetylase. F Biol Chem 1979;254:1716-23.

10 Norton VG, Imai BS, Yau P, et al. Histone acetylation reduces nucleosome core particle linking number change. reduces nucleosome $1989 ; 57: 449-57$.

11 Csordas A. On the biological role of histone acetylation. Biochem $\mathcal{F}$ 1990;265:23-38.

12 Taunton J, Hassig CA, Schreiber SL. A mammalian histone deacetylase related to the yeast transcriptional regulator Rpd3p. Science 1996; 272:408-11.

13 Yoshida M, Kijima M, Akita M, Beppu T. Potent and specific inhibition of mammalian histone deacetylase both in vivo and in vitro by trichostatin A. 7 Biol Chem 1990;265:17174-9.

14 Yoshida M, Nomura S, Beppu T. Effects of trichostatin on differentiation of murine erythroleukemia cells. Cancer Res 1987;47:3688-91.

15 Yoshida M, Beppu T. Reversible arrest of proliferation of rat 3Y1 fibroblasts in both the G1 and G2 phases by trichostatin A. Exp Cell Res 1988;117:122-31.

16 Dion LD, Goldsmith KT, Tang D, et al. Amplification of recombinant adenoviral transgene products occurs by inhirecombinant adenoviral transgene products occurs by in

17 Huang N, Katz JP, Martin DR, et al. Inhibition of IL-8 gene expression in Caco-2 cells by compounds which induce histone hyperacetylation. Cytokine 1997;9:27-36.
18 Musgrove EA, Lilischkis R, Cornish AL, et al. Expression of the cyclin-dependent kinase inhibitors p16 $6^{\mathrm{INK} 4}, \mathrm{p} 15^{\mathrm{INK} 4 \mathrm{~B}}$ and $\mathrm{p} 21^{\mathrm{WA}}$

19 Brasaemle DL, Attie AD. Microelisa reader quantitation of fixed, stained, solubilized cells in microtitre dishes. Biotechniques 1988;6:418-19

20 Harb J, Vavasseur F, Chadeneau C, et al. Expression of alkaine phosphatase in murine lymphoma cells. Biochem Biophys Res Commun 1991;177:125-33.

21 Chomczynski P, Sacchi N. Single-step method of RNA isolation by acid guanidinium thiocyanate-phenol-chloroform extraction. Anal Biochem 1987;162:156-9.

22 Whitehead RH, Young GP, Bhathal PS. Effects of short chain fatty acids on a new human colon carcinoma cell line (LIM 1215). Gut 1986;27:1457-63.

23 Gamet L, Daviaud D, Denis-Pouxviel C, et al. Effects of short-chain fatty acids on growth and differentiation of the human colon-cancer cell line HT-29. Int f Cancer 1992;52: $286-9$.

24 Siavoshian S, Blottière HM, Le Foll E, et al. Comparison of the effect of different short chain fatty acids on the growth and differentiation of human colonic carcinoma cell lines in vitro. Cell Biol Int 1997;21:281-7.

25 McBain JA, Eastman A, Nobel CS, et al. Apoptotic death in adenocarcinoma cell lines induced by butyrate and other histone deacetylase inhibitors. Biochem Pharmacol 1997;53: 1357-68.

26 Nakano K, Mizuno T, Sowa Y, et al. Butyrate activates the WAF1/Cip1 gene promoter through Sp1 sites in a 553-negative human colon cancer cell line. F Biol Chem 1997;272:22199-206.

27 Heerdt BG, Houston MA, Augenlicht LH. A direct link between core histone acetylation and transcriptionally active chromatin. Cell Growth Differ 1997;8:523-32.

28 Lallemand F, Courilleau D, Sabbah M, et al. Direct inhibition of the expression of cyclin D1 gene by sodium butyrate. Biochem Biophys Res Commun 1996;229:163-9.

29 Kiess M, Gill RM, Hamel PA. Expression of the positive regulator of cell cycle progression, cyclin D3, is induced during differentiation of myoblasts into quiescent myotubes. Oncogene 1995;10:159-66.

30 Jiang $\mathrm{H}$, Lin J, Su ZZ, et al. Induction of differentiation in human promyelocytic HL-60 leukemia cells activates p21, WAF1/CIP1, expression in the absence of p53. Oncogene 1994;9:3397-406.

31 Steinman RA, Hoffman B, Iro A, et al. Induction of p21 (WAF-1/CIP1) during differentiation. Oncogene 1994;9: 3389-96.

32 Hodin RA, Meng S, Archer S, et al. Cellular growth state differentially regulates enterocyte gene expression in 647-53.

33 Goldberg Y, Nassif II, Pittas A, et al. The anti-proliferative effect of sulindac and sulindac sulfide on HT-29 colon cancer cells: alterations in tumor suppressor and cell cycle-regulatory proteins. Oncogene 1996;12:893-901.

34 Harper JW, Elledge SJ, Keyomarsi K, et al. Inhibition of cyclin-dependent kinases by p21. Mol Biol Cell 1995;6: 387-400.

35 Sowa Y, Orita T, Minamikawa S, et al. Histone deacetylase inhibitor activates the WAF1/Cip1 gene promoter through the Sp1 sites. Biochem Biophys Res Commun 1997;241:142-

36 Blottière HM, Zennadi R, Grégoire M, et al. Analysis of the relationship between stage of differentiation and NK/LAK susceptibility of colon carcinoma cells. Int 7 Cancer 1993;53:409-17.

37 Park C, Chamberlin ME, Pan CJ, et al. Differential expression and butyrate response of human alkaline phosphatase genes are mediated by upstream DNA elements Biochemistry 1996;35:9807-14.

38 Bohm SK, Gum JR, Erickson RH, et al. Human dipeptidyl peptidase IV gene promoter: tissue-specific regulation from TATA-less GC-rich sequence characteristic of a housekeeping gene promoter. Biochem $\mathcal{F}$ 1995;311:835-43.

39 Arts J, Lansink M, Grimbergen J, et al. Stimulation of tissuetype plasminogen activator gene expression by sodium butyrate and trichostatin $\mathrm{A}$ in human endothelial cells involves histone acetylation. Biochem f 1995;310:171-6.

40 Whitlock JP Jr, Galeazzi D, Schulman H. Acetylation and calcium-dependent phosphorylation of histone $\mathrm{H} 3$ in nuclei from butyrate-treated HeLa cells. F Biol Chem 1983; 258:1299-304.

41 Parker MI, De Haan JB, Gevers W. DNA hypermethylation in sodium butyrate-treated WI-38 fibroblasts. 7 Biol Chem in sodium butyrate-

42 Cuisset L, Tichonicky L, Jaffray P, et al. The effects of sodium butyrate on transcription are mediated through activation of a protein phosphatase. $\mathcal{F}$ Biol Chem 1997;272: $24148-53$.

43 El-Deiry WS, Tokino T, Waldman T, et al. Topological control of $\mathrm{p} 21^{\mathrm{WAF} 1 / \mathrm{CIP} 1}$ expression in normal and neoplastic tissues. Cancer Res 1995;55:2910-19.

44 Yasui W, Akama Y, Yokozaki hours, et al. Expression of p2 $1^{\mathrm{WAF} 1 / \mathrm{CIP} 1}$ in colorectal adenomas and adenocarcinomas and its correlation with $\mathrm{p} 53$ protein expression. Pathol Int 1997;47:470-7.

45 Li YJ, Laurent-Puig P, Salmon RJ, et al. Polymorphisms and probable lack of mutation in the WAF1-CIP1 gene in colorprobable lack of mutation in the Oncogene 1995;10:599-601.

46 Shiohara M, El-Deiry WS, Wada M, et al. Absence of WAF1 mutations in a variety of human malignancies. Blood 1994; 84:3781-4. 